\title{
Linguistic security as a factor of sustainable development of a region(on the example of Scandinavian Peninsula)
}

\author{
Vera Budykina \\ Chelyabinsk State University, Br. Kashirinykh St., 129, 454021 Chelyabinsk, Russia
}

\begin{abstract}
The article is devoted to the study of problems of linguistic security as a factor of sustainable development of a region; special attention is paid to the preservation of languages of indigenous peoples and national minorities. The article describes the experience of the Scandinavian countries in the field of maintaining and revitalizing of the Sami languages and the main conventions on the protection of the rights of indigenous peoples and languages, as well as languages of national minorities. Moreover, the author explores how Sami language learning is organized and implemented in Scandinavian schools and if it contributes to the preservation and development of the Sami language. The language policies of Finland, Sweden and Norway in relation to the Sami languages, the achievements and shortcomings of the policy are analyzed. The paper offers a critical review of the core elements of Sami language policies to implement the positive experience in the maintaining of the languages of the national minorities and indigenous languages of the Russian Federation as an essential part of linguistic security which in its turn leads to sustainable development of the country.
\end{abstract}

\section{Introduction}

Modern globalization processes permeate almost all spheres of society's existence and cannot but influence the state's language policy both in relation to its interaction with other countries of the international community, and in relation to participants in cross-language communication within a single state. As for communication at the international level, the discussions most often concern the role and status of English language as a language of international communication, dominating other languages that participate in international communication, including Russian. This problem was extensively explored in the scientific works of many Russian scientists (Khaleeva 2006 [1], Gritsko 2011 [2], Zhigalyov 2015 [3], etc.). Thus, the Vice-Chancellor of Moscow State university, Professor I. Khaleevaconsiders English,which is as the major means of communication worldwide, to be the major threat towards the Russia's national security [1].

The problem of linguistic security and indigenous languages arises in a lot of countries. There are some researches on the language situation in New Zealand [4], Ireland [5], Africa [6], and etc. Within the framework of this research, we are most interested in the problem of linguistic security within the state, the problem of preserving the state language and other 
languages used on the territory of a particular state, as a factor of sustainable development of the region. The Countries of Scandinavian Peninsula has had a rich experience in maintaining minority languages and it was chosen as an object of our research.

\section{Materials and Methods}

In Russia, the term "Linguistic security" was first used by the President of the Guild of Linguistic Experts in Documentation and Information Disputes, Doctor of Sciences (in Linguistics), Professor M. V. Gorbanevsky in 2002 at the research seminar "Theory and practice of linguistic analysis of media texts in forensic examinations and information disputes" [7].

Doctor of Law and Philology, E. I. Galyashina, speaking at the same seminar, expanded the scope of use of this term by talking about the need to observe the technique of linguistic security during the preparation of official documents, as well as the threat of digital document management and low level of voice communication on the Internet for the security of the state, including linguistic security, etc. [8].

Many Russian scientists (Yu. A. Belchikov, N. D. Golev, etc.) reduce the understanding of linguistic security to violations in language and speech related to the expression of value judgments, opinions, assumptions, insults and slander, insults based on national or racial affiliation, etc. This position is completely explained by the fact that the issue of linguistic security arose from the increasing number of forensic linguistic examinations and was initially based solely on the intersection of two sciences: law and linguistics.

Subsequently, the term has acquired a broader interpretation and is now more often associated with ensuring the national security of the state through ensuring the linguistic security of the state language, and the preservation of other national languages. Currently, linguistic security is viewed from two main perspectives: as an object for threats to national security and as a means to achieve/maintain national security. It is necessary to continuously study the experience of other countries and search for new practices and solutions to develop the right language policy in the Russian Federation. The purpose of this research is to study the experience of the Scandinavian countries in relation to language policy, and, above all, in relation to the preservation of indigenous and minority languages.

For the countries of the Scandinavian peninsula which are actively working towards the preservation of state languages, the problem of maintaining the languages of national minorities and the languages of indigenous peoples, especially the Sami language, comes to the fore, which is reflected in a number of research papers published in Norway, Finland and Sweden (Skuttnabb-Kangas 1994 [9], Sammalahti 1998 [10], Pikkarainen and Brodin 2008 [11], etc.).

Moreover,online debates over the past five years about the Sami languages in a national context were critically analyzed. A sociocultural theoretical framework is used to analyze the data. Overall, the paper offers a critical review of the core elements of Sami language policy to implement the positive experience in the maintaining of indigenous languages of the Russian Federation as a part of linguistic security which in its turn leads to sustainable development of the country.

\section{Results and Discussions}

The Sami are a group of indigenous inhabitants of the former historical region of Lapland, which today is split between four states: Norway, Sweden, Finland and Russia. Ten different Sami languages are structurally and lexically comparable, but differ to the same extent as romance languages, so they are not mutually intelligible. 
According to the Atlas of the world's endangered languages, nine languages are at risk of extinction to some extent, with one, Akkala Sami, having ceased to exist in 2003. In Norway and Sweden, five of the nine Sami languages are preserved: Southern Sami, Pite Sami, Lule Sami, Ume Sami, and Northern Sami. According to recent estimates, the total number of Sami people ranges from 50,000 to 150,000, and only half of them are native speakers of the Sami language. The Northern Sami are by far the largest group, with 20,000 to 23,000 speakers in Norway and 5,000 to 7,000 in Sweden, while each of the other groups has fewer than 600 people [12]. According to various estimates, the number of Sami people in Finland ranges from 6,000 to 9,500. In present-day Finland threeSami languages are spoken-Inari Sami(300 to 400 native speakers), Northern Sami(about 2,000 native speakers), andSkolt Sami(about 400 native speakers), with an estimated total of 6,000 Sami people.

Like many indigenous groups internationally, the Sami were subject to a policy of assimilation from the 1850s until the end of World War II. All school education in Norway was to be conducted in Norwegian from 1880 onwards. In 1902, a law was passed, under which the state-owned land in the northernmost county of Norway, Finnmark, was sold or loaned exclusively to native Norwegian speakers. Belonging to national minorities was considered a major disadvantage [13]. The situation in Sweden and Finland was similar.

In the 1950s and 1960s, a period of "worldwide ethnic awakening" began [ibid.]. In 1989, the ILO Convention 169 on indigenous and tribal peoples in independent countries [14] was established, taking into account the international norms contained in the 1957 Convention on indigenous and other tribal peoples.

To ensure the linguistic security of a united Europe, the European Charter for Regional or Minority Languages was adopted in Strasbourg in 1992 [15]. The document justified the need to create favorable conditions for the preservation and development of regional and ethnic minority languages. The Framework Convention for the protection of national minorities then followed [16]. Norway has ratified all three conventions. However, Norway's ratification of the framework Convention was unique, as it took an unprecedented decision to exclude the Sami from the list of national minorities. The reason for this, as Pietikäinen and others explain [17], is that the Sami already enjoy indigenous status in Norway, and therefore minority status, which is a lower status, should not apply to them. "Most indigenous peoples do not accept to be labeled as "minority" [18]. The Sami are included in the other two ratifications. Sweden has not ratified ILO Convention 169 by 2020. This was initially explained by the fact that "Sweden does not comply with the conditions set out in the Convention regarding land rights". Finland has also thus far refrained from ratifying this document.

Some regulations have also been adopted at the national level, and national constitutions have been amended as a way to protect the rights of indigenous peoples and languages. Thus, in January 2017, after long negotiations and consultations, the three countries signed the Sami Convention [19], which expands the definition of Sami representatives who have the right to cast their votes in elections to the Sami parliaments of Norway, Sweden and Finland. Russia did not take part in the development of the Convention.

In 1987, the Sami Parliament was created; later, national commissions on Sami rights were formed, which also consider issues of language preservation.Norway formed the Sami language policy faster than Sweden and Finland, which was caused by a wave of protests on the Alta river.

In all the Scandinavian countries, there is a very limited number of Sami schools in Sami regions and most children have the right to get their education in the Sami language. In most cases, students studying Sami can choose between Sami as their first or second language. A wide scale study about the Sami language learning at Norwegian schools conducted by KittLyngsnes [20] has showed that outside the Sami regions the Sami 
language subject was taught in Sami while other subjects and afterschool activities were mostly taught in Norwegian. Besides, there was a lack of qualified Sami teachers and relevant educational resources and learning materials. In some cases, the Sami was the second language of instruction used in the process distance learning and extracurricular activities.

Lyngsnes also states that $15 \%$ of respondents (i.e. parents in Sami areas) didn't find that it is essential for Sami children to study the Sami language and the same number found it vital. While explaining the reason why their children didn't study the Sami, they mentioned the lack of relevant educational resources. Another reason was that according to the Norwegian curriculum, the time for instruction in the Sami was taken from the time for instruction in Norwegian. According to the study mentioned above, in the Sami secondary school there are 100 students, 8 of them are studying Southern Sami: 7 of them as a second language and 1 as his first language [20]. On the whole, it was found that the Sami language as a subject at school is not enough to revitalize and maintain the language, it must be more actively used within the Sami community, let alone Sami families. So, the old English saying "Use it or lose it" relates to the indigenous Sami languages.

\section{Conclusion}

Despite the positive results achieved, there are still problems in all countries of the Scandinavian Peninsula, such as the inability to use the Sami language as a language of communication with authorities; in courts and hospitals, in workplaces; and the almost complete absence of schools that implement educational programs in Sami languages, textbooks and other literature. Furthermore, speaking about the achievements of the countries of the Scandinavian Peninsula in terms of maintaining the indigenous languages, one should bare in mind that the problem of the Sami was widely covered in the media and caused the greatest resonance in the political and cultural environment. Thanks to this, significant results were actually achieved, which, unfortunately, cannot be said for other small peoples and linguistic minorities of Sweden, Norway, and Finland.

In summation, both in Russia and the countries of the Scandinavian Peninsula, much remains to be done for the preservation and prosperity of both the state languages and the languages of indigenous peoples and national minorities. The positive experience gained by the countries of the Scandinavian peninsula in terms of the Sami language preservation and revitalization should be used in the development of the Russian Federation language policy. In Russia, there are still many unresolved problems, some languages are completely disappearing, and the development of an effective language policy remains one of the major tasks. Without solving this problem, the sustainable development of the state or the region is impossible.

\section{References}

1. I.I. Khaleeva, Bulletin of the Russian Academy of Sciences, 76, 104 (2006)

2. M.I. Gritsko, IdeasandIdeals, 3, 63 (2011)

3. B.A. Zhigalyov, The Authority, 10, 32 (2015)

4. A.R. Beckeyeva, Russian Journal of Linguistics, 2, 31 (2014)

5. J. Pecnikova, A. Slatinska, Russian Journal of Linguistics, 1, 40 (2019)

6. E.J. Francis, The European Conference on Language Learning 2014: Official Conference Proceedings, 65 (2014) 
7. M. V. Gorbanevsky, The price of the word: from the practice of linguistic expertise of media texts in court proceedings (2002)

8. E. I. Galyashina, Linguistics vs extremism: To help judges, investigators, and experts (2006)

9. T. Skutnabb-Kangas, Bilingualism in Deaf Education, 139 (1994)

10. P. Sammallahti, The Saami Languages. An Introduction (1998)

11. H. Pikkarainen, B. Brodin, Discrimination of National Minorities in the Education System (2008)

12. T. Rasmussen, J. Shaun Nolan, International Journal of the Sociology of Language, 209, 35 (2011)

13. L. Huss, A. Lindgren, International Journal of the Sociology of Language, 209, 1 (2011)

14. Indigenous and Tribal Peoples Convention, https://www.ilo.org/

15. European Charter for Regional or Minority Languages, https://www.coe.int

16. Framework Convention for the Protection of National Minorities, https://www.coe.int/

17. S. Pietikäinen, L. Huss, S. Laihiala-Kankainen, U. Aikio-Puoskari, P. Lane, ActaBorealia: A Nordic Journal of Circumpolar Societies, 1, 1 (2010)

18. T. Skutnabb-Kangas, R. Phillipson, Linguistic Human Rights: Overcoming Linguistic Discrimination (1994)

19. Nordic Language Convention, https://www.norden.org/

20. K.M. Lyngsnes, International Education Studies, 3, 228 (2013) 